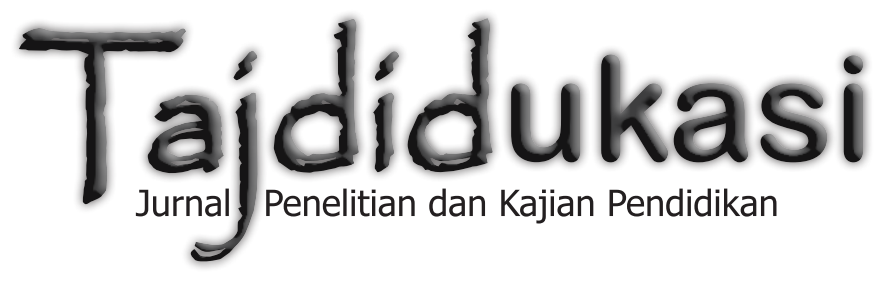




\section{Tajdidukasi}

Volume VIII, No. 1, Januari 2018

ISSN: 1979-6943

Tajdidukasi: Jurnal Penelitian dan Kajian Pendidikan merupakan jurnal Penelitian dan Kajian Pendidikan yang berisi Penelitian Tindakan Kelas (PTK) dan Penelitian Tindakan Sekolah (PTS) serta Kajian Pendidikan interdisipliner di Perguruan Tinggi yang diterbitkan Majelis Pendidikan Dasar dan Menengah Pimpinan Wilayah Muhammadiyah Daerah Istimewa Yogyakarta. Artikel hasil PTK dan PTS serta kajian pemikiran pendidikan ditulis oleh para Guru dan Kepala Sekolah serta Dosen dalam mengujicobakan metode dan strategi pembelajaran untuk meningkatkan kualitas pendidikan baik SD/MI, SMP/MTs dan SMA/MA/SMK serta Perguruan Tinggi. Artikel PTK dan PTS fokus pada mata pelajaran di sekolah/madrasah, seperti Ilmu Pengetahuan Alam (IPA), Imu Pengetahuan Sosial (IPS), Matematika, Fisika, Kimia, bahkan teknik, seperti Teknik Mesin, Elektro, Informatika dan lain sebagainya. Sementara itu, artikel Kajian Pendidikan merupakan penelitian interdisipliner dan multidisipliner yang dilakukan Dosen di Perguruan Tinggi terhadap khasanah keIslaman.

Tajdidukasi: Jurnal Penelitian dan Kajian Pendidikan adalah jurnal terbuka yang versi softfile-nya bisa dibaca dan diakses secara gratis, sementara versi print out/ hardcopy dapat diperoleh dengan menghubungi distributor di alamat serial tajdidukasi.ac.id. Sof-file keseluruhan artikel yang diterbitkan dapat diakses melalui Tajdidukasi Open Access Juornal di www.dikdasmenpwmdiy.or.id

\section{Pimpinan Editor \\ Suyadi, Universitas Ahmad Dahlan (UAD) Yogyakarta, Indonesia}

\section{Anggota Editor}

Arif Budi Raharjo, Universitas Muhammadiyah Yogyakarta (UMY), Indonesia

Achmad Muhammad, UIN Sunan Kalijaga Yogyakarta, Indonesia

Hendro Widodo, Universitas Ahmad Dahlan (UAD) Yogyakarta

Mundzirin Yusuf, UIN Sunan Kalijaga Yogyakarta, Indonesia

Sumedi, UIN Sunan Kalijaga Yogyakarta, Indonesia

Sukamto, Universitas Muhammadiyah Yogyakarta (UMY), Indonesia

Sumarsono, UIN Sunan Kalijaga Yogyakarta Indonesia

Sarjilah (Lembaga Penjaminan Mutu Pendidikan) Yogyakarta

Fathur Rahman, M.Si., Universitas Negeri Yogyakarta (UNY) Indonesia

\section{Editor Pelaksana}

Suryanto, Universitas Muhammadiyah Yogyakarta (UMY), Indonesia

Suyatno, Universitas Ahmad Dahlan (UAD) Yogyakarta

Farid Setiawan, Universitas Ahmad Dahlan (UAD) Yogyakarta

Alamat Redaksi:

Kantor Majelis Pendidikan Dasar dan Menengah Pimpinan

Wilayah Muhammadiyah D.I. Yogyakarta

Jl. Gedongkuning No. 130B Yogyakarta

Kode Pos : 55171

Telephone : (0274) 377078

Facsimile : (0274) 371718

Website : www.dikdasmenpwmdiy.or.id

E-Mail : tajdidukasi@dikdasmenpwmdiy.or.id 


\title{
IMPLEMENTASI MEDIA FLASH CARD DALAM MENINGKATKAN PENGUASAAN KOSAKATA BAHASA ARAB
}

\author{
Miftakhul Falah Islami \\ SMA Muhammadiyah 5 Yogyakarta \\ e-mail: falaah.mfi@gmail.com
}

\begin{abstract}
Abstrak
Penelitian ini bertujuan untuk mengetahui implementasi media Flash Card dalam meningkatkan penguasaan kosakata bahasa Arab. Penelitian ini termasuk dalam penelitian tindakan kelas. Subjek penelitian ini adalah siswa kelas X IIS 2 SMA Muhammadiyah 5 Yogyakarta tahun pelajaran 2017/2018. Metode yang digunakan untuk mengumpulkan data berupa observasi, tes, dokumentasi, dan catatan lapangan. Hasil penelitian menunjukkan adanya peningkatan penguasaan kosakata setelah diterapkan media Flash Card sebagai media pembelajaran. Peningkatan dapat dilihat dari nilai pre test dan nilai pos test. Nilai rata-rata kelas siklus I antara pre test dan pos test menunjukkan peningkatan nilai sebesar 48 poin dari nilai rata-rata kelas 30 poin pada pre test menjadi 78 poin pada pos test. Sehingga dapat diketahui adanya peningkatan penguasaan kosakata bahasa Arab sebelum dengan sesudah tindakan. Peningkatan belum signifikan karena nilai rata-rata kelas masih dibawah indikator keberhasilan. Dan nilai rata rata kelas pada siklus II antara pre test dan pos test menunjukkan peningkatan nilai sebesar 70 poin dari nilai rata-rata kelas 15 poin pada pre test menjadi 85 poin pada nilai pos test.
\end{abstract}

Kata Kunci: Media Flash Card, Kosakata Bahasa Arab

\section{A. PENDAHULUAN}

Pembelajaran Bahasa Arab setidaknya mencangkup pembelajaran mufradat, istima', kalam, qira 'ah, tarkib (nahwu-sharaf), dan kitabah. Mufradat (kosakata) merupakan pengenalan pertama pembelajaran bahasa Arab kepada siswa. Sehingga pada awal proses pembelajaran siswa dikenalkan dengan kosakata baru. Hal itu selaras dengan indikator KI 4 yang terdapat pada mata pelajaran pendidikan bahasa Arab kelas X kurikulum 2013 yang didalamnya memuat 2 indikator kompetensi keterampilan yang terkait dengan kosakata. yaitu mampu melafalkan dan mampu menyajikan arti kosakata bahasa Arab sesuai tema pada kompetensi dasar. Untuk menguasai banyak kosakata siswa diharuskan menghafal kosakata tersebut. Namun kadang yang terjadi hari ini hafal, besok lupa. Begitulah ingatan mereka datang dan pergi. Hal ini disebabkan karena mereka tidak familiar dengan bunyi maupun tulisan kosakata bahasa Arab. Kurang mampu- 
nya siswa membaca tulisan Arab juga menjadi salah satu penyebab mereka kurang bisa menggunakan kamus bahasa Arab. Jangankan mencari sebuah kata, untuk membuka dan membacanya saja mereka kebingungan. Hal inilah yang menjadikan pembelajaran kosakata tidak berjalan dengan baik.

Dalam pembelajaran bahasa Arab di SMA Muhammadiyah 5 Yogyakarta, masih ditemukan fenomena sebagaimana yang disinggung di atas. Hal tersebut diperkuat dengan rendahnya hasil penilaian tengah semester I yang di dapat oleh siswa kelas X IIS 2. Sehingga karenanya guru dituntut lebih aktif dan kreatif untuk bisa mengurai masalah tersebut. Supaya tujuan pembelajaran bahasa Arab bisa tercapai dengan baik. Menurut Gagne, fungsi seorang guru sebagai designer of instruction (perancang pengajaran), manager of instruction (pengelola pengajaran), dan evaluator of learning (penilai prestasi belajar siswa). (Muhibbin Syah, 2006: 250) Oleh karena itu, seorang guru dituntut untuk mempunyai berbagai keterampilan yang mendukung tugasnya dalam mengajar. Salah satu keterampilan tersebut adalah bagaimana seorang guru dapat menggunakan media pembelajaran. (Djamarah Syaiful Bahri dan Aswan Zain, 2006:164)

Terkait dengan penggunaan media, pepatah mengungkapkan: "saya dengar saya lupa, saya lihat saya ingat, saya kerjakan saya mengerti”. Ini berarti semakin banyak indera komunikan yang diterapkan oleh sinyal informasi, se- makin banyak pula pesan yang banyak diserap. Dengan demikian, penggunaan media yang bervariasi merupakan salah satu upaya yang tepat untuk meningkatkan keberhasilan kegiatan belajar dan pembelajaran. (Abdorrakhman Gintings, 2010: 140)

Kedudukan media pengajaran ada dalam komponen metode mengajar sebagai salah satu upaya untuk mempertinggi proses interaksi siswa dengan lingkungan belajarnya. Dengan menggunakan media gambar (visual) pengalaman belajar yang diperoleh siswa akan semakin bertambah. Siswa tidak hanya mendapat keterangan berupa kata-kata tapi mendapat pengalaman nyata dari visual yang ditampilkan. Alat-alat visual tidak saja menghasilkan cara belajar yang efektif dalam waktu singkat, tetapi apa yang diterima melalui alat-alat visual lebih lama dan lebih baik tinggal dalam ingatan. (Amir Hamzah Sulaeman. 1988:18) Sebuah penelitian mengemukakan bahwa pengetahuan seseorang melalui penglihatan $83 \%$ lebih besar daripada $11 \%$ melalui pendengaran. Sedangkan kemampuan daya ingat sebesar 50\% dari penglihatan dan $20 \%$ dari pendengaran. (Galih Katon Irawanto, 2009:3)

Berangkat dari pentingnya media dalam pengajaran bahasa Arab untuk mempermudah, memperjelas serta memperkuat pemahaman serta ingatan siswa terhadap apa yang telah diperolehnya, maka peneliti yang juga sebagai guru mata pelajaran Pendidikan Bahasa Arab terdorong untuk mengadakan penelitian tindakan kelas untuk me- 
ningkatkan penguasaan kosakata bahasa Arab. Hal tersebut dianggap penting agar tujuan pembelajaran mufradat pada dapat tercapai.

Fakta bahwa siswa cepat lupa akan kosakata yang telah dihafalkannya, alternatif solusi yang dapat dilakukan adalah peneliti menawarkan sebuah media pembelajaran yang lebih menarik bagi siswa yaitu media Flash Card. Berdasarkan penelitian yang telah dilakukan, Media Flash Card diyakini sebagai salah satu media yang mempunyai pengaruh yang signifikan dalam penguasaan kosakata. Diantaranya adalah penelitian yang dilakukan oleh saudari Widi Astuti yang berjudul "Pengaruh Media Flash Card Untuk Meningkatkan Perbendaharaan Kosakata Bahasa Arab Siswa Kelas VII A MTs Muhammadiyah 07 Klego Boyolali Tahun Pelajaran 2011/2012" hasil penelitian menyimpulkan bahwa media Flash Card mempunyai pengaruh yang signifikan dalam meningkatkan perbendaharaan kosakata bahasa Arab siswa kelas VII A MTs Muhammadiyah Klego Boyolali.

Adapun penelitian lainnya adalah penelitian saudari Annis Kurniawati yang berjudul "Peran Penggunaan Media Flash Card Dalam Penguasaan Kosakata Bahasa Inggris (Vocabulary) pada Materi Family Kelas I di MIN Yogyakarta". Hasil penelitian menunjukkan bahwa penggunaan Flash Card dapat lebih efektif dalam pengajaran penguasaan kosakata bahasa Inggris (vocabulary) pada materi Family kelas I di MIN Yogyakarta daripada tidak menggunakan media sama sekali.

Berdasarkan kajian di atas, penelitian ini dilakukan dengan tujuan untuk mengetahui implementasi media Flash Card dalam meningkatkan penguasaan kosakata bahasa Arab.

\section{B. METODE PENELITIAN}

Jenis penelitian yang digunakan dalam penelitian ini adalah PTK atau Classroom Action Research (CAR). Model penelitian terdiri dari: perencanaan (planning), tindakan (acting), pengamatan (observing), dan refleksi (reflecting). Keempat komponen tersebut merupakan langkah-langkah dalam sebuah siklus. Model tindakan dan pengamatan ini kemudian dijadikan sebagai dasar langkah berikutnya, yaitu refleksi. Dari hasil refleksi kemudan disusun sebuah modifikasi dalam bentuk tindakan dan pengamatan lagi untuk siklus selanjutnya. (Suharsimi Arikunto, 2006:83)

Penelitian ini dilaksanakan pada hari Kamis, 8 Februari 2018 dan hari Kamis, 22 Februari 2018 semester II tahun pelajaran 2017/2018 dengan Subjek penelitian siswa kelas X IIS 2 SMA Muhammadiyah 5 Yogyakarta tahun pelajaran 2017/2018. Adapun objek penelitian ini adalah peningkatan penguasaan kosakata bahasa Arab dengan menggunakan media Flash Card.

Tehnik yang dipakai dalam mengumpulkan data yaitu observasi, wawancara, tes, dan refleksi. Sedangkan teknik yang dipergunakan untuk men- 
ganalisis adalah reduksi data, trianguasi, display data dan kesimpulan. Indikator keberhasilan dalam penelitian ini adalah jika terdapat peningkatan nilai ratarata kelas antara hasil pos test dengan hasil pre-test dari satu siklus ke siklus selanjutnya. Dan nilai rata-rata pos test mencapai nilai angka 80 .

\section{HASIL DAN PEMBAHASAN}

1. Pelaksanaan

a. Siklus I

Pelaksanaan kegiatan belajar mengajar pada siklus 1 dilaksanankan pada tanggal 8 Februari 2018 pada siswa kelas X IIS 2 SMA Muhammadiyah 5 Yogyakarta dengan jumlah 15 siswa laki-laki dan 10 siswa perempuan. Adapun proses pemberian siklus mengacu pada rencana pelaksanaan pembelajaran yang telah disiapkan.

\section{1) Perencanaan}

Pada tahapan ini, sebelum peneliti melakukan tindakan di kelas, peneliti melakukan persiapan dan perencanaan tindakan supaya dalam pelaksanaannya dapat berjalan dengan runtut dan sesuai dengan yang diharapkan. Olah karena itu, beberapa perencanaan yang peneliti lakukan diantaranya:

a) Menyiapkan Rencana Pelaksanaan Pembelajaran (RPP) sesuai dengan KD yang akan dipelajari.

b) Menyiapkan Media Flash Card sesuai dengan materi pada $\mathrm{KD}$

c) Menyaiapkan panduan/langkahlangkah penggunaan media Flash Card d) Membuat lembar evaluasi.

Dari beberapa hal yang telah peneliti lakukan dalam tahap perencanaan, selanjutnya peneliti melaksanakan pembelajaran siklus I. Secara ringkas pelaksanaan tindakan diuraikan sebagai berikut:

2) Pelaksanaan

Pada pelaksanaan tindakan kelas siklus I dilaksanakan pada hari Kamis, 8 Februari 2018 selama 2 jam pelajaran. Yaitu pada jam ke 5-6 (jam 10.15-11.45 WIB) di kelas X IIS 2 SMA Muhammadiyah 5 yogyakarta. Selama 90 Kegiatan belajar mengajar berlangsung, guru membagi waktu tersebut menjadi 3 tahapan kegiatan. Yaitu: kegiatan pendahuluan, kegiatan Inti, dan kegiatan penutup.

Pada kegiatan pendahuluan. Guru menyiapkan siswa untuk siap menerima pelajaran. Deiantaranya dengan cara mengajak berdo'a, mengecek ketertiban siswa, mengecek kehadiran siswa, menyampaikan tujuan pembelajaran, menyampaikan proses kegiatan yang akan dilakukan, melakukan pre test, membagi siswa menjadi beberapa kelompok kerja, memberikan lembar panduan penggunaan media Flash Card, dan memberikan Media Flash Card.

Pada kegiatan Inti, masing-masing kelompok siswa mempelajari lembar panduan Penggunaan media Flash Card sebagaiman yang telah disampaikan oleh guru. Setelahnya, setiap kelompok siswa diminta untuk belajar kosakata behasa Arab dengan menggunakan 
Flash Card sebagaimana yang terdapat pada panduan. Selama 20 menit siswa belajar kosakata secara kelompok, kemudian guru meminta 2 siswa pada setiap kelompok untuk maju kedepan kelas dan mempraktikkan hasil belajar dengan menggunakan media Flash Card di depan kelompok yang lain. Sembari guru melakukan penilaian unjuk kerja dan memilih kelompok yang terbaik dalam kelas tersebut.

Setalah masing-masing wakil kelompok selesai mempraktikkan belajar dengan menggunakan media Flash Card di depan kelas, kemudian guru mengambil alih kegiatan kelompok dengan melakukan evaluasi secara klasikal kepada seluruh siswa. Evauasi tersebut dilakukan secara lisan dan bersamasama dengan cara siswa diminta untuk menyebutkan kosakata sebagaimana Flash Card yang guru tunjukkan secara acak dan bergantian. Pertama guru menunjukkan gambar pada Flash Card dan siswa diminta untuk menyebutkan kosakata dalam bahasa Arabnya dan yang kedua guru menunjukkan tulisan Arab yang terdapat pada media Flash Card dan siswa diminta untuk menebak gambar/artinya.

Pada kegiatan penutup. Guru lemberikan soal pos test sebagai evaluasi proses pembelajaran dan implementasi media Flash Card. Setelah 15 menit siswa mengerjakan soal pos test. guru kemudian menyampaikan kegiatan yang akan dilakukan pada pertemuan selanjutnya dan diakhiri dengan penutup.
3) Pengamatan

Berdasarkan hasil pengamatan peneliti beserta kolabolator terhadap situasi pembelajaran pada siklus I, ditemukannya beberapa siswa yang belum sepenuhnya bisa mengikuti pembelajaran dengan menggunakan media Flash Card dengan baik. Hal ini terlihat dari siswa yang masih bingung dan belum terbiasa dalam menggunakan media Flash Card dalam belajar. Sehingga dalam penggunaan media Flash Card belum maksimal dan beberapa siswa yang lain terlihat belum merasa senang belajar dengan mengggunakan Flash Card.

Dari hasil pre test dan pos test, terdapat peningkatan Nilai antara nilai pre test dengan Nilai pos test. Akan tetapi, dari beberapa jawaban siswa pada pre test dan pos test terlihat kesukaran siswa dalam penguasaan maharah kitabah. Hal tersebut peneliti uangkapkan karena masih banyak siswa yang telah hafal kosakata secara lisan, tetapi ketika diuji dengan tes tertulis masih banyak ditemukan siswa yang kurang tepat dalam menuliskan kosa kata bahasa Arabnya. Walaupun secara maksudnya sudah benar. Hal itu terjadi karena mayoritas siswa lebih fokus terhadap maksud gambar dan cara menyebutkan kosakata bahasa Arabnya.

Selain itu, banyaknya waktu diawal pelajaran yang tidak maksimal karena pelaksanaan tindakan siklus I berada setelah jam pendidikan jasmani dan rohani. Sehingga dalam mengkondisikan siswa untuk siap belajar bahasa 
Arab memerlukan waktu 20 menit. Hal itu mempengaruhi waktu sebagaimana yang telah direncanakan dan berkurangnya waktu belajar.

4) Refleksi

Implentasi media Flash Card dalam meningkatkan penguasaan kosakata bahasa Arab diangggap berhasil jika terdapat peningkatan penguasaan kosakata yang ditunjukkan adanya peningkatan nilai yang didapat siswa pada pre test dengan pos test. dan nilai rata-rata kelas mencapai nilai angka 80. Dari pengamatan peneliti dan kolabolator sebagaimana yang diuraikan di atas, pelaksanaan tindakan pada siklus I belum maksimal. Selain adanya kendala waktu yang terpotong untuk menyiapkan siswa siap belajar, dari pelaksanaan penerapan media Flash Card sebagai media pemebelajaran dirasa memerlukan penjelasan secara langsung dan memerlukan waktu lebih lama sebagai pembiasaan. Sehingga dalam pelaksanaan siswa telah terbiasa menggunakan media Flash Card. Kekurangan perhatian siswa terhadap penguasaan maharah al-Kitabah juga perlu diingatkan kembali supaya pada penilaian siswa mampu menuliskan mufradat secara tepat sebagaimana yang dipelajari. Dari hasil pre test dan pos test yang dilaksanakan juga belum menampakkan hasil yang memuaskan. Hal itu terlihat dari rata-rata nilai pos test siklus I yang masih berada dibawah nilai angka 80 sebagaimana Indikator keberhasilan yang telah ditetapkan untuk penelitian ini. Oleh karena itu, peneliti merasa masih perlu dilakukan tindakan kembali pada siklus II untuk dapat mencapai hasil yang maksimal.

b. Siklus II

Pelaksanaan kegiatan belajar mengajar pada siklus II dilaksanankan 2 minggu setelah dilaksanakannya siklus I. Hal itu dilakukan untuk memberi jeda waktu dan dilakukan pembelajaran seperti biasanya tanpa menghadirkan media Flash Card. Adapaun pelaksanaan siklus II terlaksana pada tanggal 22 Februari 2018 pada siswa kelas X IIS 2 SMA Muhammadiyah 5 Yogyakarta dengan jumlah 15 siswa laki-laki dan 10 siswa perempuan. Sebagaimana pada siklus I, proses tindakan juga mengacu pada rencana pelaksanaan pembelajaran sebagaimana yang telah disiapkan.

1) Perencanaan

Sebagaima tahap perencanaan siklus I, Pada tahapan perencanaan siklus II peneliti juga melakukan persiapan dan perencanaan tindakan supaya dalam pelaksanaannya dapat berjalan dengan baik dan bisa menutup kekurangan dan kelemahan sebagaimana hasil refleksi siklus I. adapaun beberapa perencanaan yang peneliti lakukan antara lain:

a) Menyiapkan Rencana Pelaksanaan Pembelajaran (RPP) sesuai dengan KD yang akan dipelajari.

b) Menyiapkan Media Flash Card sesuai dengan materi pada KD

c) Menyaiapkan panduan/langkahlangkah penggunaan media Flash Card

d) Membuat lembar evaluasi. 
e) Menyiapkan reward bagi siswa terbaik dan kelompok terbaik

Dari beberapa perencanaan yang telah peneliti lakukan, selanjutnya peneliti melaksanakan pembelajaran siklus II. Secara ringkas pelaksanaan tindakan dapat diuraikan sebagai berikut:

2) Pelaksanaan

Pelaksanaan tindakan kelas siklus II dilaksanakan pada hari Kamis, 22 Februari 2018 selama 2 jam pelajaran. Yaitu pada jam ke 5-6 (jam 10.15-11.45 WIB) di kelas X IIS 2 SMA Muhammadiyah 5 yogyakarta. Selama 90 menit kegiatan belajar mengajar berlangsung, guru membagi waktu tersebut menjadi 3 tahapan kegiatan. Yaitu: kegiatan pendahuluan, kegiatan Inti, dan kegiatan penutup.

Sebagaimana pada penerapan pada siklus I, kegiatan pendahuluan yang dilakukan Guru diantaranya menyiapkan siswa untuk siap menerima pelajaran dengan cara mengajak berdo'a, mengecek ketertiban siswa, mengecek kehadiran siswa, menyampaikan tujuan pembelajaran, menyampaikan proses kegiatan yang akan dilakukan, melakukan pre test, membegi siswa menjadi beberapa kelompok kerja, memberikan lembar panduan penggunaan media Flash Card, dan memberikan media Flash Card.

Pada kegiatan Inti, masing-masing kelompok siswa kembali mempelajari lembar panduan Penggunaan media Flash Card sebagaiman yang telah dilakukan pada siklus I. Setelahnya, setiap kelompok siswa diminta untuk belajar kosakata behasa Arab dengan menggunakan media Flash Card sebagaimana yang terdapat pada panduan. Selama siswa belajar kosakata secara kelompok, guru melakukan penilaian unjuk kerja dan memilih 2 siswa pada setiap kelompok untuk maju mewakili kelompoknya mempraktikkan hasil belajar dengan menggunakan media Flash Card di depan kelompok yang lain.

Sebelum masing-masing wakil kelompok mempraktikkan penggunaan Flash Card di depan kelompok yang lain, guru menyampaikan bahwa akan memberikan reward kepada kelompok yang paling cepat, dan paling banyak menyebutkan kosakata yang terdapat pada media Flash Card. Hal tersebut berdampak pada antusias dan kompetisi antar kelompok meningkat. Sehingga berpengaruh pada fokus seluruh siswa kepada setiap wakil kelompok yang maju di depan.

Setalah masing-masing wakil kelompok selesai mempraktikkan belajar dengan menggunakan media Flash Card di depan kelas, kemudian guru kembali nmengambil alih kegiatan kelompok dengan melakukan evaluasi secara klasikal kepada seluruh siswa. Evauasi tersebut dilakukan secara lisan dan bersama-sama dengan cara siswa diminta untuk menyebutkan kosakata sebagaimana Flash Card yang guru tunjukkan secara acak dan bergantian. Pertama guru menunjukkan gambar pada Flash Card dan siswa diminta untuk menyebutkan kosakata dalam 
bahasa Arabnya dan yang kedua guru menunjukkan tulisan Arab yang terdapat pada media Flash Card dan siswa diminta untuk menebak gambar/artinya.

Pada kegiatan penutup. Guru kembali memberikan soal pos test sebagai evaluasi proses pembelajaran dan implementasi media Flash Card. Setelah 10 menit siswa mengerjakan soal pos test. guru kemudian menyampaikan kegiatan yang akan dilakukan pada pertemuan selanjutnya dan diakhiri dengan penutup.

\section{3) Pengamatan}

Berdasarkan hasil pengamatan peneliti terhadap situasi pembelajaran pada siklus II, hasil yang diperoleh lebih memuaskan dibanding pada siklus I, hal tersebut ditunjukkan dari meningkatnya antusias siswa dalam belajar dengan menggunakan media Flash Card, terlaksananya penggunaan media Flash Card sesuai dengan panduan yang telah direncanakan, dan kendala pada siklus I sebagaimana telah dijelaskan pada refleksi siklus I bisa dihindari. Hanya saja, ada 8 siswa yang terlambat karena ada pembinaan dari sekolah terkait lomba. Sehingga ke-8 siswa tersebut tidak mengikuti pre test. Sedangkan kegiatan yang lain dapat mengikuti dengan baik.

Analisis dari hasil pre test dan pos test juga ada peningkatan signifikan pada penguasaan kosakata bahasa Arab siswa. Hal itu ditunjukkan dengan meningkatnya nilai antara pre test dengan pos test.

\section{4) Refleksi}

Sama dengan refleksi siklus I, implentasi media Flash Card dalam meningkatkan penguasaan kosakata bahasa Arab diangggap berhasil jika terdapat peningkatan penguasaan kosakata yang ditunjukkan dengan adanya peningkatan nilai yang didapat siswa antara nilai pre test dengan nilai pos test. dan nilai ratarata nilai pos test mencapai nilai angka 80 sebagaimana indikator keberhasilan penelitian ini. Sebagaimana pengamatan yang dijelaskan di atas, pelaksanaan siklus II sudah sesuai dengan harapan dan perencanaan yang dilakukan. Hal itu ditunjukkan dengan meningkatnya antusias siswa dalam belajar dengan menggunakan media Flash Card, dan beberapa kendala dalam kebingungan siswa dalam menerapkan media Flash Card sebagai media pembelajaran dapat diminimlisir di awal pelajaran. Selain itu, berdasarkan hasil antara pre test dan pos test juga terlihat peningkatan nilai yang signifikan antara nilai nilai rata-rata pre test sebesar 30 ke angka 85 pada nilai rata-rata pos test siklus II. Sehingga karenanya peneliti memutuskan bahwa implementasi media flash Card dalam meningkatkan penguasaan bahasa Arab pada siswa kelas X IIS 2 SMA Muhammadiyah 5 Yogyakarta dicukupkan sampai siklus II.

\section{Pembahasan}

Pada sub bab ini, dibahas bagaimana hasil dari implementasi media Flash Card dalam meningkatkan penguasaan kosakata bahasa Arab siswa kelas X 
IIS 2 SMA Muhammadiyah 5 Yogyakarta Tahun Pelajaran 2017/2018 yang dipaparkan berdasarkan siklus yang telah dilakukan. Pembahasan diuraikan berdasarkan siklus tindakan dengan membandingan nilai pre test dengan pos test siklus I untuk mengetahui adakah peningkatan penguasaan kosakata bahasa Arab setelah pernerapan media Flash Card pada siklus I, membandingkan nilai pre test dengan pos test siklus II untuk mengetahui adakah peningkatan penguasaan kosakata pada pernerapan media Flash Card pada siklus II, dan membandingkan rerata antar siklus untuk mengetahui seberapa peningkatan dan sejauh mana ketercapaian penguasaan kosakata bahasa Arab setelah diterapkannya media Flash Card sebagai media pembelajaran bahasa Arab di kelas X IIS 2 SMA Muhammadiyah 5 Yogyakarta tahun Pelajaran 2017/2018 sebagaimana telah ditentukan pada indikator keberhasilan penelitian.

\section{a. Siklus I}

Berdasarkan pelaksanaan siklus I implementasi media Flash Card dalam meningkatkan penguasanaan kosakata bahasa Arab siswa kelas X IIS 2 SMA Muhammadiyah 5 Yogyakarta tahun ajaran 2017/2018 pada hari kamis, 8 Februari 2018. Didapatkan hasil pre test dan pos test sebagaimana berikut:
Tabel 1. Daftar nilai Pre test dan Pos test siklus I

\begin{tabular}{|r|l|c|c|c|}
\hline \multirow{2}{*}{ No } & \multirow{2}{*}{ Nama } & \multicolumn{3}{|c|}{ Nilai } \\
\cline { 3 - 5 } & & Pre test & Pos test & Rentang \\
\hline 1 & ANA & 30 & 100 & 70 \\
\hline 2 & BAMP & 30 & 70 & 40 \\
\hline 3 & BKP & 10 & 40 & 30 \\
\hline 4 & DPP & 0 & 60 & 60 \\
\hline 5 & DNK & - & - & - \\
\hline 6 & DRA & 20 & 90 & 70 \\
\hline 7 & DR & 60 & 90 & 30 \\
\hline 8 & ETM & 40 & 70 & 30 \\
\hline 9 & FR & 10 & 60 & 50 \\
\hline 10 & FM & 50 & 100 & 50 \\
\hline 11 & FS & 30 & 100 & 70 \\
\hline 12 & HNP & 0 & 70 & 70 \\
\hline 13 & IIW & 60 & 90 & 30 \\
\hline 14 & IJP & 20 & 30 & 10 \\
\hline 15 & INN & 0 & 70 & 70 \\
\hline 16 & JSK & 10 & 80 & 70 \\
\hline 17 & JB & 0 & 70 & 70 \\
\hline 18 & KWH & 10 & 80 & 70 \\
\hline 19 & MRA & 60 & 100 & 40 \\
\hline 20 & NK & 30 & 80 & 50 \\
\hline 21 & NP & - & - & - \\
\hline 22 & NF & 20 & 60 & 40 \\
\hline 23 & NR & 50 & 100 & 50 \\
\hline 24 & NSTU & 40 & 80 & 40 \\
\hline 25 & ORAA & 70 & 100 & 30 \\
\hline 26 & SNR & 50 & 90 & 40 \\
\hline 27 & SMA & 50 & 80 & 30 \\
\hline 28 & HHD & - & - & - \\
\hline \multirow{2}{*yyyy}{ Nilai } & $\mathbf{7 0}$ & $\mathbf{1 0 0}$ & $\mathbf{3 0}$ \\
\hline Maksimal & Nilai & $\mathbf{0}$ & $\mathbf{3 0}$ & $\mathbf{3 0}$ \\
\hline Minimal & Rata-rata & $\mathbf{3 0}$ & $\mathbf{7 8}$ & $\mathbf{4 8}$ \\
Nilai Kelas & & & & \\
\hline & & & \\
\hline
\end{tabular}

Dari tabel di atas, dapat diketahui bahwa terdapat peningkatan nilai yang 
berfariasi yang diperoleh masingmasing siswa antara nilai pre test dengan nilai pos test. nilai minimal pada kegiatan pre test siklus I menunjukkan nilai angka 0 , sedangkan nilai minimal pada kegiatan pos test nenunjukkann nilai angka 30 . Sehinggga dapat dikatakan terdapat peningkatan nilai dari pre test dengan pos test sebesar 30 . Nilai maksimal pada kegiatan pre test siklus I menunjukkan nilai angka 70, sedangkan nilai maksimal yang didapat pada kegiatan pos test menunjukkan angka 100. Sehinggga dapat dikatakan terdapat peningkatan nilai sebesar 30 .

Nilai rata-rata kelas pada kegiatan pre test siklus I menunjukkan pada angka 30, sedangkan nilai rata-rata kelas pada kegiatan pos test menukkan angka 78 . Sehingga ada peningkatan nilai sebesar 48. Dari penjabaran tersebut, dapat disimpulkan bahwa pada pelaksanaan penerapan media Flash Card dalam meningkatkan penguasaan kosakata bahasa Arab siswa kelas X IIS 2 SMA Muhammadiyah 5 Yogyakarta terdapat peningkatan nilai antara sebelum tindakan dengan nilai setelah tindakan.

Walaupun pada kesimpulan tersebut sudah menunjukkan adanya peningkatan penguasaan kosakata bahasa Arab yang ditunjukkan oleh meningkatnya nilai antara nila pre test dan pos test yang dilakukan, peneliti ini belum sianggap berhasil karena nilai rata-rata kelas masih berada dibawah nilai indikator keberhasilan sebagaimana telah ditentukan. Oleh karena itu, peneliti merasa masih perlu menunjukkan dan menjabarkan nilai pre test dan pos test pada siklus II untuk mengetahui masih adakah peningkatan nilai yang di dapat oleh siswa kelas X IIS 2 pada tindakan siklus II. Dan sejauh mana peningkatan pada rata-rata pos test yang diperoleh.

b. Siklus II

Sebagaimana pelaksanaan siklus II implementasi media Flash Card dalam meningkatkan penguasanaan kosakata bahasa Arab siswa kelas X IIS 2 SMA Muhammadiyah 5 Yogyakarta tahun ajaran 2017/2018 pada hari kamis, 22 Februari 2018. Didapatkan hasil pre test dan pos test sebagaimana berikut:

Tabel 2. Daftar nilai Pre test dan Pos test siklus II

\begin{tabular}{|c|c|c|c|c|}
\hline \multirow[b]{2}{*}{ No } & \multirow[b]{2}{*}{ Nama } & \multicolumn{3}{|c|}{ Nilai } \\
\hline & & Pre test & Pos test & Rentang \\
\hline 1 & ANA & 20 & 100 & 80 \\
\hline 2 & BAMP & & 70 & 70 \\
\hline 3 & BKP & & 80 & 80 \\
\hline 4 & DPP & - & - & - \\
\hline 5 & DNK & - & - & - \\
\hline 6 & DRA & 10 & 100 & 90 \\
\hline 7 & DR & 0 & 80 & 80 \\
\hline 8 & ETM & 10 & 100 & 90 \\
\hline 9 & FR & & 100 & 100 \\
\hline 10 & FM & & 70 & 70 \\
\hline 11 & FS & 20 & 100 & 80 \\
\hline 12 & HNP & 20 & 70 & 50 \\
\hline 13 & IIW & 0 & 80 & 80 \\
\hline 14 & IJP & 0 & 50 & 50 \\
\hline 15 & INN & & 100 & 100 \\
\hline 16 & JSK & 20 & 100 & 80 \\
\hline 17 & JB & & 70 & 70 \\
\hline 18 & KWH & 0 & 90 & 90 \\
\hline 19 & MRA & 0 & 100 & 100 \\
\hline 20 & NK & 30 & 80 & 50 \\
\hline
\end{tabular}


Miftakhul Falah Islami - Implementasi Media Flash Card Dalam Meningkatkan Penguasaan Kosakata ....

\begin{tabular}{|c|l|c|c|c|}
\hline \multirow{2}{*}{ No } & Nama & \multicolumn{3}{|c|}{ Nilai } \\
\cline { 3 - 5 } & & Pre test & Pos test & Rentang \\
\hline 21 & NP & 30 & 90 & 60 \\
\hline 22 & NF & 40 & 100 & 60 \\
\hline 23 & NR & 20 & 70 & 50 \\
\hline 24 & NSTU & 10 & 60 & 50 \\
\hline 25 & ORAA & - & - & - \\
\hline 26 & SNR & 20 & 100 & 80 \\
\hline 27 & SMA & - & - & 90 \\
\hline 28 & HHD & $\mathbf{N}$ & $\mathbf{1 0 0}$ & $\mathbf{6 0}$ \\
\hline $\begin{array}{r}\text { Nilai } \\
\text { Maksimal }\end{array}$ & $\mathbf{4 0}$ & $\mathbf{5 0}$ & $\mathbf{5 0}$ \\
\hline $\begin{array}{c}\text { Nilai } \\
\text { Minimal }\end{array}$ & $\mathbf{0}$ & $\mathbf{8 5}$ & $\mathbf{7 5}$ \\
\hline $\begin{array}{c}\text { Rata-rata } \\
\text { Nilai Kelas }\end{array}$ & $\mathbf{1 5}$ & & \\
\hline
\end{tabular}

Dari tabel di atas, dapat diketahui bahwa terdapat peningkatan nilai yang berfariasi yang diperoleh masing-masing siswa antara nilai pre test dengan nilai pos test. nilai minimal pada kegiatan pre test siklus II menunjukkan nilai angka 0 , sedangkan nilai minimal pada kegiatan pos test nenunjukkann nilai angka 50. Sehinggga dapat dikatakan terdapat peningkatan nilai minimal kelas antara pre test dengan pos test sebesar 50. Nilai maksimal pada kegiatan pre test siklus II menunjukkan nilai angka 40, sedangkan nilai maksimal yang didapat pada kegiatan pos test menunjukkan angka 100. Sehinggga dapat dikatakan terdapat peningkatan nilai sebesar 60 .

Nilai rata-rata kelas pada kegiatan pre test siklus II menunjukkan pada angka 15, sedangkan nilai rata-rata kelas pada kegiatan pos test menunjukkan angka 85 . Sehingga ada peningkatan nilai sebesar 70. Dari penjabaran tersebut, dapat disimpulkan bahwa pada pelaksanaan penerapan media Flash Card dalam meningkatkan penguasaan kosakata bahasa Arab siswa kelas X IIS 2 SMA Muhammadiyah 5 Yogyakarta terdapat peningkatan nilai antara sebelum tindakan dengan nilai setelah tindakan. Dan nilai rata-rata kelas yang diperoleh juga sudah mencapai nilai indikaor keberhasilan pada penelitian ini.

Berdasarkan penjabaran di atas, bisa disimpulkan bahwa penerapan media Flash Card dalam pembelajaran mempunyai pengaruh yang signifikan dalam meningkatkan penguasaan maupun perbendaharaan kosakata sama halnya penelitian yang telah dilakukan oleh Widi Astuti pada skripsinya dan relevan juga dengan kesimpulan pada jurnal Emprit Hotimah dan jurnal Ika Widyasari, Kartika Chrysti Suryandari, dan Suripto yang menyatakan bahwa penerapan media Flash Card mempu meningkatkan penguasaan kosakata.

\section{KESIMPULAN}

Berdasarkan hasil penelitian dan pembahasan yang telah diuraikan di atas, diperoleh kesimpulan bahwa: (1) Implementasi media Flash Card dapat meningkatkan antusiasme dan motivasi siswa dalam pembelajaran kosakata bahasa Arab siswa kelas X IIS 2 SMA Muhammadiyah 5 Yogyakarta. Hal tersebut dibuktikan dari pengamatan peneliti dan hasil pengamatan kolabolator selama pelaksanaan penerapan media 
Flash Card sebagaiman telah dijelaskan pada pembahasan. (2) Penerapan Media Flash Card pada pelajaran bahasa Arab dapat meningkatkan penguasaan kosakata bahasa Arab siswa kelas X IIS 2 SMA Muhammadiyah 5 Yogyakarta. Hal tersebut ditunjukkan dengan nilai pre test dan nilai pos test siswa yang mangalami peningkatan nilai yang berfariasi antara siswa satu, dengan siswa yang lain pada siklus I dan Siklus II. Nilai minimal dan nilai maksimal antar siklus juga mengalami peningkatan dengan nilai yang berfariasi. nilai rata-rata kelas pada siklus I antara pre test dan pos test juga menunjukkan peningkatan nilai rata-rata kelas sebesar 48 poin dari nilai 30 poin pada pre test ke nilai 78 poin pada pos test. Hal itu telah menunjukkan adanya peningkatan penguasaan kosakata sebelum dan sesudah tindaka. Hasilnya belum signifikan karena masih belum mencapai indikator keberhasilan. Sedangkan nilai rata rata kelas pada siklus II antara nilai pre test dan nilai pos test menunjukkan peningkatan nilai srata-rata kelas ebesar 70 poin dari nilai 15 poin pada pre test ke nilai 85 poin pada nilai pos test. Hal tersebut menunjukkan adanya peningkatan penguasaan kosakata yang signifikan. Karena peningkatan yang dicapai sudah mencapai nilai indikator keberhasilan penelitian yang dilakukan.

\section{DAFTAR PUSTAKA}

Ahmadi, Abu dan Supriyono Widodo, 1991, Psikologi Belajar, Jakarta: Rineka Cipta
Arikunto Suharsimi, 2006, Prosedur Penelitian Suatu Pendekatan Praktik, Jakarta: Rineka Cipta

Arikunto Suharsimi, 2007, Penelitian Tindakan Kelas, Jakarta: Bumi Aksara

Arikunto Suharsimi. 2006. Prosedur Penelitian Suatu Pendekatan Praktik. Jakarta: Rineka Cipta

Arsyad Azhar, 2010, Bahasa Dan Metode Pengajarannya: Beberapa Pokok Pikiran, Yogyakarta: Pustaka Belajar

Astuti, Widi. 2012. Pengaruh Media Flash Card Untuk Meningkatkan Pembendaharaan Kosa Kata Bahasa Arab Siswa kelas VII A Mts Muhammadiyah 07 Klego Boyolali. skripsi Pendidikan Bahasa Arab Fakultas Tarbiyah Dan Keguruan UIN Sunan Kalijaga Yogyakarta

Azwar Syaefudin, 1998, Metode Penelitian, Yogyakarta: Pustaka Pelajar Depdiknas, 2002, Kamus Besar Bahasa Indonesia, Jakarta: Balai Pustaka Djamarah, Syaiful Bahri dan Zain, Aswan. 2006. Strategi Belajar Mengajar. Jakarta: PT Rineka Cipta Gintings, Abdorrakhman. 2010. Esensi Praktis Belajar Dan pembelajaran. Bandung: Humaniora

Hotimah, Empit. 2010. "Penggunaan Media Flashcard Dalam Meningkatkan Kemampuan Siswa Pada Pembelajaran Kosakata Bahasa Inggris Kelas II MI Ar-Rochman Samarang Garut." Jurnal Pendidi- 
kan Universitas Garut, Vol. 04, No. 01: $10-18$

Irawanto, Galih Katon. 2009. Pemanfaatan Media Komputer Sebagai Upaya Meningkatkan Prestasi Belajar Siswa Dalam Pembelajaran Fikih Di Kelas VIII B MTsN Maguwoharjo. Skipsi Fakultas Tarbiyah dan Keguruan UIN sunan Kalijaga Yogyakarta

Kurniawati, Annis. 2011. Peran Penggunaan Media Flash Card dalam Penguasaan Kosakata Bahasa Inggris (Vocabulary) Pada Materi Family Kelas I di MIN Yogyakarta II. Skripsi UIN Sunan Kalijaga Yogyakarta

Lexy, Moleong J., 1997, Metodologi Penelitian Kualitatif, Bandung: Remaja Rosda Karya

Nurchanifah, Siti, 2010, Implementasi Media Gambar dalam Pembelajaran Kosakata Bahasa Arab Untuk Usia Sekolah Dasar. Skripsi, Fakultas Tarbiah Jurusan Pendidikan Bahasa Arab Uin Sunan Kalijaga Yogyakarta.

Nurkancana Wawan dan P. P. N. Surantana, 1986, Evaluasi Pendidikan, Surabaya: Usaha Nasional
Sudjana Nana dan Ibrahim, 1989, Penelitian Dan Penilaian Pendidikan, Bandung: Sinar Baru Algasindo

Sudjana, Nana dan Rivai, Ahmad, 1990, Media Pengajaran (Penggunaan Dan Pembuatannya), Bandung, CV Sinar Baru

Sudjana, Nana, 1990, Penelitian Hasil Proses Belajar Mengajar, Bandung: PT. Remaja Rosdakarya

Sulaeman Amir Hamzah, 1988, Media Audio-Visual, Jakarta: PT Gramedia Syah Muhibbin, 2002, Psikologi Belajar, Jakarta: Balai Pustaka

Syah, Muhibbin. 2006. Psikologi Pendidikan Dengan Pendekatan Baru. Bandung: PT. Remaja Rosdakarya Widyasari, Ika. Chrysti Suryandari, Kartika. Suripto. 2016. "Penerapan Metode Permainan Melalui Media Flash Card Dalam Peningkatan Kemampuan Kosakata Bahasa Inggris Siswa Kelas Iv Sdn 2 Kebasen". Jurnal FKIP UNS, Vol. 5, No 6:

Wiriaatmadja Rochayati, 2008, Metode Penelitian Tindakan Kelas: Untuk Meningkatkan Kinerja Guru Dan Dosen, Bandung: PT. Remaja Rosdakarya 